\title{
THE RESTORATION AND CONSERVATION OF EGYPTIAN ALABASTER VESSELS FROM THE EARLY ERA IN ATFIYAH MUSEUM STORE - HELWAN - EGYPT
}

\author{
Rabea Radi Abdel Kader ${ }^{a}$, Shaimaa Sayed Mohamed ${ }^{\text {b, * }}$ \\ ${ }^{\text {a }}$ Manager of Atfiyah restoration authority- Ministry state of Antiquities -Egypt- Egyptianconservators2013@ gmail.com \\ ${ }^{\mathrm{b}}$ Conservator in Fayoum- Ministry state of Antiquities - Egypt- Egyptianconservators2013@gmail.com
}

KEY WORDS: Conservation, Egyptian Alabaster, Early era, museum store, vessels, Funerary furniture, statues, canopic jars

\begin{abstract}
:
Egypt is considered one of the most countries which contain a lot of cultural heritage; the Ancient Egyptian used a lot of stones for his life like: limestone, sandstone, granite and Egyptian Alabaster.

The Egyptian Alabaster is used for his daily and eternal life, he made a lot of funerary furniture from this stone like: vessels, statues, Architectural elements in the temples, tombs and canopic jars to preserve his viscera from decomposition like: stomach, liver ...etc in the mummification process.

Egyptian Alabaster is a sedimentary rock especially chemical- origin sedimentary rocks, it deposits inside caves and around springs which consists of calcium carbonates ( $\mathrm{CaCO} 3)$, they are very fragile "hardness $=3$ in Mohs hardness scale ".

The Egyptian Alabaster vessels expose to a lot of deterioration factors in the burial and exposure environment after excavation.

The study case vessels are made of Egyptian alabaster stone and belong to the early era (First and second Egyptian dynasties) in Atfiyah museum store, these vessels exposed to a lot of deterioration factors in the burial and exposure environment like: soil pressure, air temperature variety, relative humidity and salts.

The vessels are conserved at the restoration laboratory in Atfiyah museum store by a lot of restoration and conservation processes like: cleaning - consolidation - assembling process for the separated parts and completion for the lost parts.
\end{abstract}

\section{1-INTRODUCTION}

Alabaster was used a lot in vessels making and sculpturing from Badry's civilization, the first and second Nakada (Prehistory era) in lower and upper Egypt, Alabaster becomes one from the most important elements in funeral furniture ${ }^{(*)}$ Figure (1).

The manufacturing of alabaster vessels and statues were very prosperous in the old kingdom ${ }^{(* *)}$, for example: the extracted alabaster vessels from the step pyramid in Saqqara (Egypt) which belonged to the third dynasty ${ }^{(* * *)}$.Figure (2).

\footnotetext{
${ }^{(*)}$ Raffaele, F.,2005,"Stone vessels in Early dynastic Egypt", "Cahiers Caribeens d, Egyptologie, No 7-8 ,France, P:1

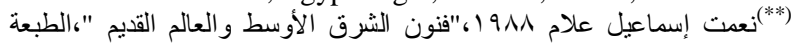
الخامسة ،دار المعارف ،القاهرة ،صدئ

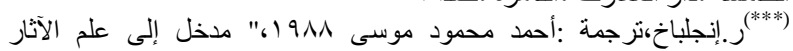

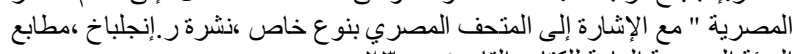

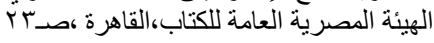

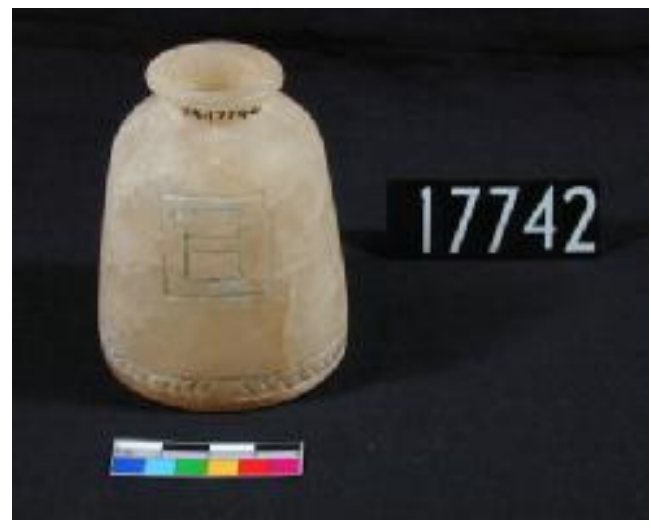

Figure 1: Alabaster vessel from prehistory era in the British museum 


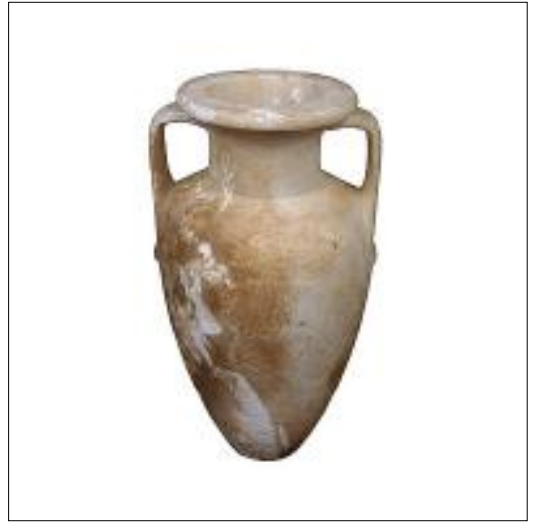

Figure 2: Alabaster vessel from the third dynasty (the step pyramid) in the Egyptian museum- Egypt

In the Middle Kingdom, Petri found a lot of Alabaster vessels in the burial chamber of the king Amenmemhat III in his pyramid in Hawara- Fayoum ${ }^{(*)}$, Also the Alabaster vessels making was very prosperous in the New Kingdom.

The Alabaster stone consists of calcium sulphates $\left(\mathrm{CaSO}_{4}\right)$ but Egyptian alabaster consists of calcium carbonates (calcite) $\left(\mathrm{CaCO}_{3}\right)$ which is classified as a secondary chemical deposition in lime stones formations also as a result of lime stones weathering and recrystalization in the caves, it's a chemically formed sedimentary rock, the hardness of calcite is " 3 " in Mohs hardness scale and its specific density is $2.71 \mathrm{gm} / \mathrm{Cm} 3$ ${ }^{(* *)}$. Acids are very harmful to its structure when we add hydrochloric acid to Egyptian alabaster, it will be effervescence because of the reaction between calcium carbonates and the hydrochloric acid ${ }^{(* * *)}$.

\section{2-MATERIALS AND METHODS}

The case study is an Egyptian alabaster vessel from the ancient era (the second dynasty) which is preserved in Atfiyah museum store in Giza - Egypt, its number in the archaeological record is (814).

We took two samples from invisible positions in the selected vessel to study its mineral composition and the deterioration phenomena.

The first sample was analyzed with X-ray Diffraction (XRD); the results were that the sample consisted mainly of Calcium Carbonates $\left(\mathrm{CaCO}_{3}\right)$ as the main composition of Egyptian Alabaster stone. Figure (3)

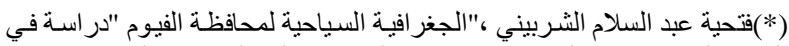

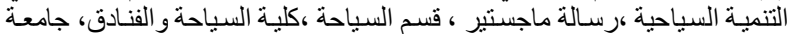

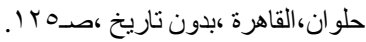

(**)Al Dokkan.2001,"Egyptian technology", building and ornamental stones of Egypt http://www.Aldokkan.com/art/stone.htm

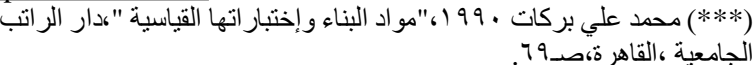

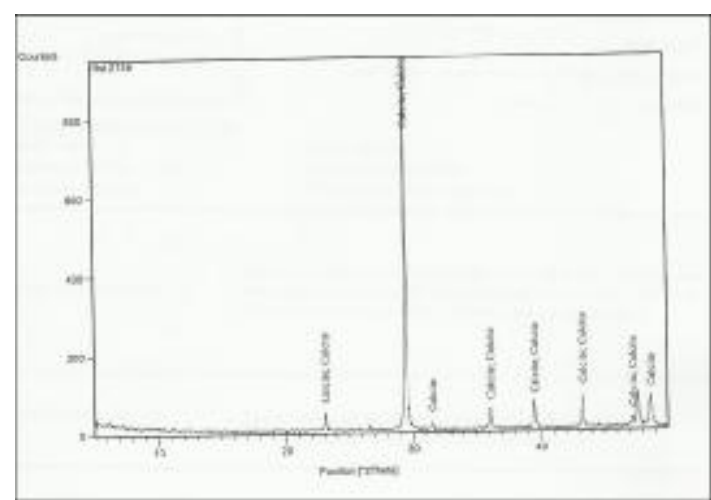

Figure 3: The XRD analysis for the first sample

The second sample was examined with Scanning Electron Microscope (SEM) and analyzed with the attached unit with it (EDAX); EDAX gave us an elemental analysis for the sample as shown. Figure $(4,5)$

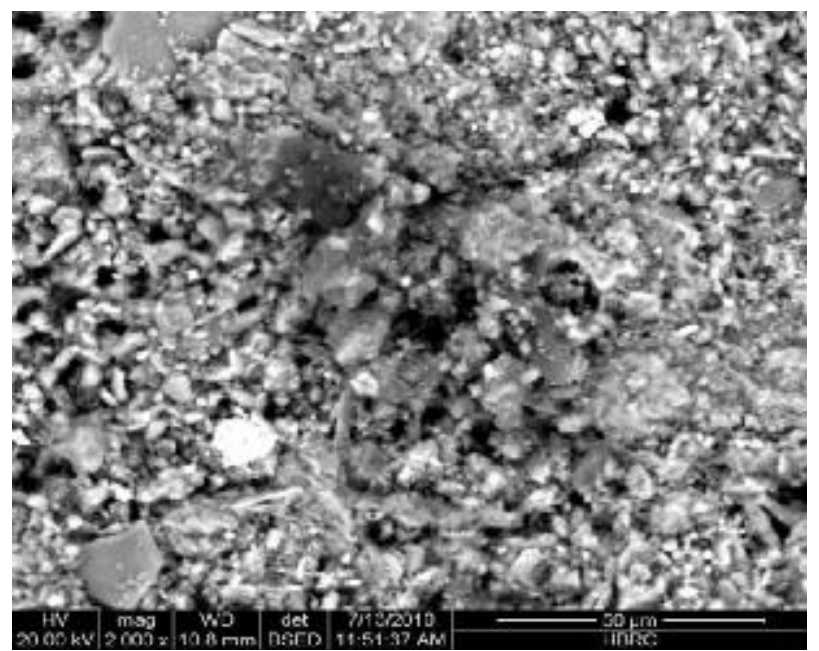

Figure 4: The Examination of the second sample with SEM (Magnification 2000X)

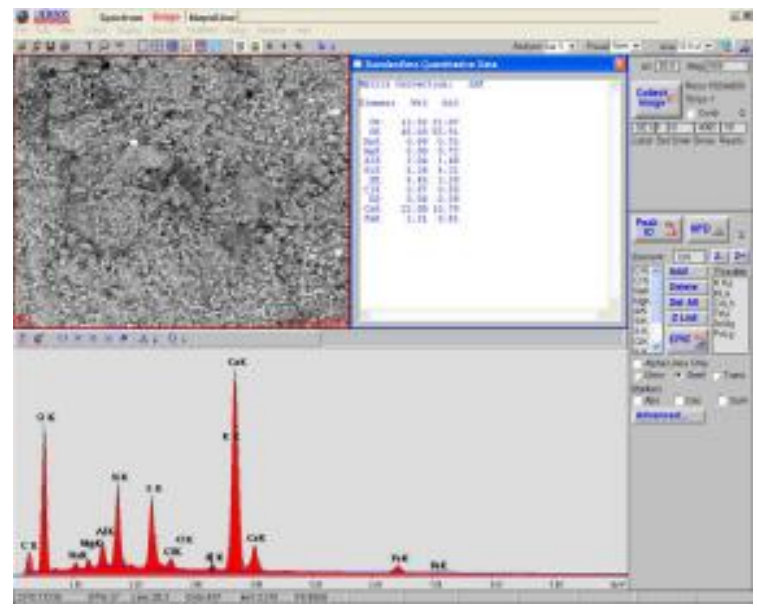

Figure 5: The Analysis of the second sample with EDAX unit 


\section{3- THE CONSERVATION PROCESSES OF THE SELECTED VESSEL}

\section{3-Cleaning process:}

First, the fine dust was removed mechanically with smooth brushes in order not to scratch the weak surface of the vessel .Second, the soil crusts were wetted with distilled water and removed with scalpels, and the remains of crusts were removed with ethyl alcohol and cleaned with distilled water to remove the solvent' remains . Figure (6).

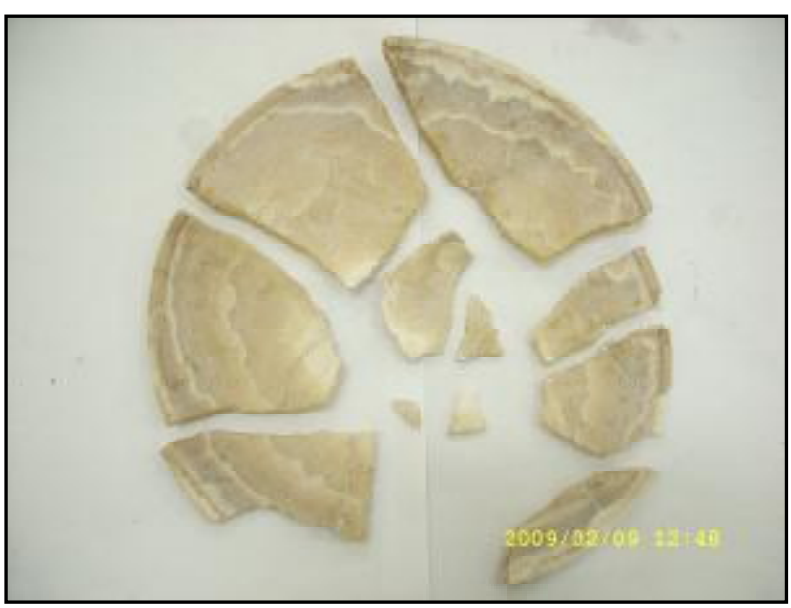

Figure 6 : The selected vessel after cleaning

\section{3-Consolidation process:}

The Consolidation process is considered one of the most important processes in the conservation work; the chosen consolidant was Wacker $(\mathrm{OH}) 100$ because of its good penetration inside the narrow pores of the alabaster stone.

We used Wacker $(\mathrm{OH}) 100$ in the percentage of $2 \%$ in ethyl alcohol as a solvent, it was applied by brushing in 3 consolidation courses and we waited for the complete drought of the each consolidation course.

\section{3-Assembling process:}

The vessel was broken in 11 separated parts; it was needed to be assembled. First, we tried to find the right place for the each part before adhesive's application, Araldite 1092 was used for the assembling process because of its reversibility and good adhesion.

\section{3- Completion process:}

The completion process was done for the lost part of the vessel to save the stabilization and balance of the object, first we closed the lost part in the base with clay until we prepared the completion paste (Egyptian alabaster stone's powder mixed with Wacker $(\mathrm{OH}) 100$ dissolved in ethyl alcohol in the proportion of $15 \%$ ), the paste was applied on the lost parts in vessel. Figure (7).

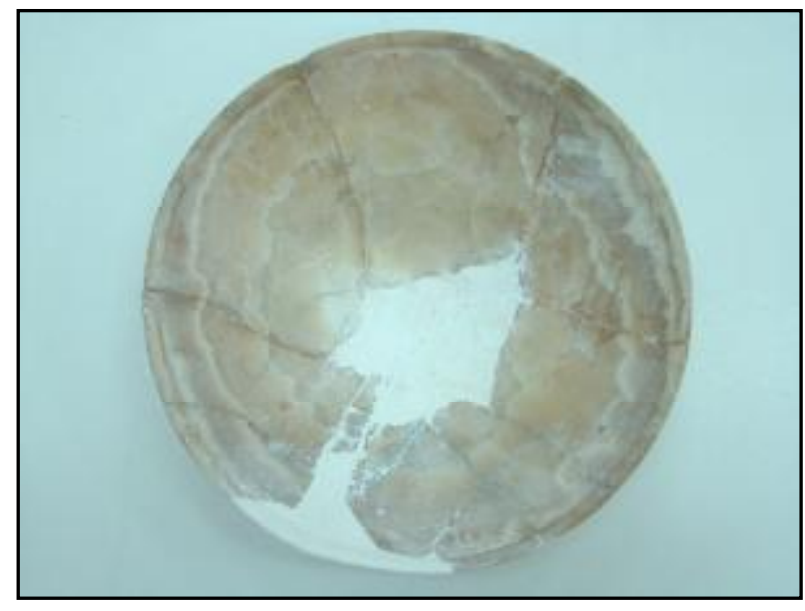

Figure 7: The selected Egyptian alabaster's vessel after assembling, completion and all conservation

Processes

\section{4- RESULTS AND DISCUSSION}

From the case study, we found that the burial and exposure environment had a severe effect on the coherence of Egyptian alabaster's physical structure, in the bad conditions; there will be a lot of deterioration factors cause the collapsing and weakness of the alabaster in the end like: soil deposits pressure, relative humidity and air temperature varieties between the burial and exposure environment, salts and air pollution.

\section{5- CONCLUSION}

The Egyptian alabaster was used a lot in vessels, funeral furniture, canopic jars making and sculpturing, it was used also in architectural elements making through the ages from the pharaonic age to the Islamic age, its hardness is 3 According to Mohs hardness scale, it is not hard enough to stand the deterioration factors in the both burial and exposure environment so it become very weak.

\section{6- REFERENCES}

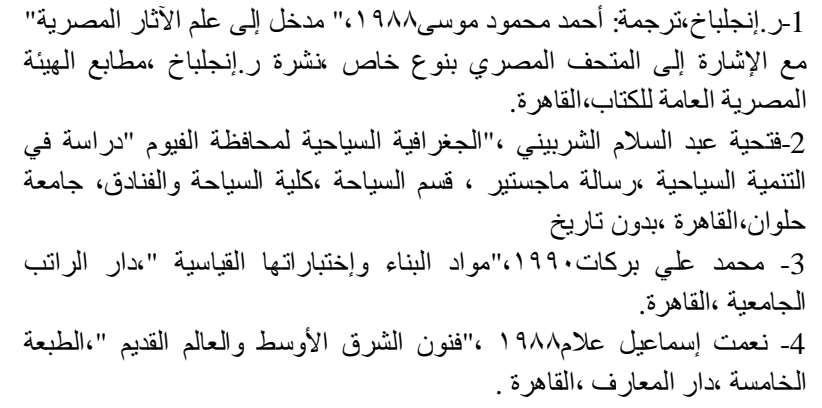

5- Al Dokkan, 2001,"Egyptian technology", building and ornamental stones of Egypt, http://www.Aldokkan.com/art/stone.htm. 
6- Raffaele, F., 2005,"Stone vessels in early dynastic Egypt",

"Cahiers Caribeens d, Egyptologie, No 7-8, France.

\section{7- ACKNOWLEDGMENT}

For building and housing researches center in Dokki- Egypt, The restoration department in Atfiyah museum store - Helwan - Egypt and prof.Mohamed Abdel Hady- professor of Antiquities' Restoration and Conservation - Faculty of Archaeology -Cairo University- Egypt. 